\title{
PENGARUH PENGELOLAAN KELAS TERHADAP HASIL BELAJAR PESERATA DIDIK PADA PEMBELAJARAN IPS KELAS VIII SMPN 7 SUNGAI AMBAWANG
}

\author{
Muhammad Dahlan, Aminuyati, F. Y. Khosmas \\ Program Studi Pendidikan Ilmu Pengetahuan Sosial FKIP Untan Pontianak \\ Email:ajadahlan52@gmail.com
}

\begin{abstract}
This study aims to determine the magnitude of "The Influence of Class Management on Student Learning Outcomes in Social Studies Learning Class VIII SMPN 7 Sungai Ambawang". This study uses a quantitative approach in the form of correlation research. The research population was all students of class VIII SMPN 7 Sungai Ambawang, namely 40 students and the samples taken in this study were 40 students. The variables studied were Class Management $(X)$ with Social Studies Learning Outcomes (Y). The method used in this research is descriptive in the form of quantitative methods, namely systematically describing the influence of class management on social studies learning outcomes for class VIII students. The sample in this study was the entire population of class VIII SMPN 7 Sungai Ambawang, totaling 40 students. The results showed that the t-count is 5.144 that there is a positive and significant influence between classroom management on student learning outcomes in social studies learning class VIII SMPN 7 Sungai Ambawang through simple linear regression obtained $Y=59.235+0.260 X$. which means the constant value is 59.235. While the value of the regression coefficient of the class management variable is positive at 0.260 . How big is the percentage of the influence of classroom management on learning outcomes based on the coefficient of determination $R$ square 0.410 , or $41 \%$ while the remaining $59 \%$ is influenced by other variables. The results of the study can be concluded that there is a positive and significant effect of classroom management on student learning outcomes.
\end{abstract}

Keywords: Classroom Management, Social Studies Learning Outcomes

\section{PENDAHULUAN}

Pendidikan dan manusia sejatinya tidak dapat dipisahkan karena pendidikan merupakan kunci membuka masa depan insan yang dikaruniai dengan akal dan pemikiran. Pendidikan memegang peranan vital dan krusial untuk menjamin keberlangsungan hidup suatu bangsa dan negara karena pendidikan merupakan wadah pengembangan kualitas manusia sebagai kegiatan yang bermakna dan terjaga.

Tentang perintah membaca, dimana dengan membaca manusia akan memperoleh ilmu untuk mengembangkan sifat-sifatnya serta kedudukan yang berilmu dan berakal. Kegiatan pendidikan adalah kegiatan yang bertujuan dan mempunyai tujuan, oleh karena itu dalam pelaksanaannya merupakan suatu proses yang berkesinambungan pada setiap jenis dan jenjang pendidikan, yang kesemuanya berkaitan dalam suatu sistem pendidikan.

Secara umum tujuan pendidikan diatur dalam Undang-Undang Republik Indonesia Nomor 22 Tahun 2003 tentang Sistem Pendidikan Nasional dalam Bab II Pasal 3 yang isinya sebagai berikut: Tujuan 
pendidikan pendidikan nasional adalah tentang mengembangkan potensi peserta didik agar menjadi yang maha kuasa, berakhlak mulia, berilmu, sehat, cakap, kreatif, mandiri bertakwa, berakhlak mulia, berakal, cakap, kreatif, bertakwa, mandiri, dan warga negara yang bertanggung jawab dan bertanggung jawab (SISDIKNAS), maka pendidikan berperan. peranan penting dalam meningkatkan sumber daya manusia dan etika.

Menurut Rusdiana (2015, p. 165) mengatakan bahwa: Pengelolaan kelas dibutuhkan lantaran berdsarkan dari hari ke hari, bahkan berdasarkan waktu ke waktu, perilaku dan perubahan siswa selalu berubah. Hari ini siswa bisa belajar dengan baik dan tenang, tapi besok mungkin tidak sama. Kemarin ada persaingan sehat di grup, sebaliknya hari ini tidak serius, jadi persaingannya tidak sehat. Kelas akan selalu dinamis dalam hal perilaku, sikap, mental dan emosional. Tidak dapat disangkal bahwa kelas adalah lingkungan belajar yang diciptakan atas dasar kecerdasan bersama seorang siswa yang relatif berkomunikasi untuk memiliki tujuan yang sama, kesamaan kekuatan tujuan dalam pengelolaan.

Pengelolaan dan realisasi kelas adalah proses belajar mengajar yang harus efektif agar dapat diterima. Seorang pengajar bertanggung jawab untuk memberikan materi pembelajaran, tetapi yang menjadi penangan dan pencernanya adalah siswa dengan kemampuan, bakat dan latar belakang yang berbeda, sehingga siswa dapat memahami sepenuhnya materi pembelajaran yang disiapkan olehnya.

Tercapai atau tidaknya tujuan pendidikan nasional tidak terlepas dari determinan pendidikan yaitu pendidik, peserta didik, lingkungan pengajaran dan alat yang digunakan dalam proses pendidikan, kata Barnadib (2010, p.35). Faktor penentu pendidikan tidak dapat dipisahkan karena semuanya saling mempengaruhi. Faktor pendidikan adalah orang yang bertanggung jawab atas pendidikan. Marimba (2010, p. 37) karena tanggung jawab pendidik yang cukup berat, gelar ini hanya dapat diemban oleh orang dewasa Hasbullah (2010, p. 19).

Guru sebagai pendidik dijadikan sebagai landasan dan keyakinan yang kuat terhadap perubahan dan peningkatan kualitas peserta didik. Jadi seorang guru dalam menjalankan tanggung jawab dan fungsinya dikenal sebagai arsitek pembelajaran, merancang pembelajaran dengan sempurna. Tugas guru dapat terlaksana dengan sempurna apabila dilandasi oleh konsep pembelajaran yang baik, sehingga pencapaian tujuan yang telah ditetapkan dalam proses pembelajaran dapat diukur. Oleh karena itu, guru diminta untuk meningkatkan peran dan keterampilannya, karena lebih mudah bagi guru yang berkualitas untuk meningkatkan pembelajarannya secara lebih efektif dan efisien sehingga dapat mengelola kelasnya dengan lebih baik.

Setiap pengajar melakukan yang terbaik untuk memastikan bahwa kelasnya dikelola dengan baik, manajemen yang baik tergantung pada: pertama, guru dengan cepat mempelajari faktor-faktor yang mendorong praktik kondisi pembelajaran yang menguntungkan. Kedua, diketahui masalahmasalah yang sering muncul yang dapat mempengaruhi lingkungan belajar. Ketiga, menguasai berbagai pendekatan pengelolaan kelas dan kita juga mengetahui kapan dan untuk masalah apa pendekatan tersebut digunakan menurut Latuconsina (2013, p. 133).

Sebagai seorang profesional, guru dituntut memiliki keterampilan dalam pengelolaan kelas, yaitu menciptakan dan memelihara kondisi pembelajaran yang optimal untuk mencapai tujuan pembelajaran. Kelas adalah tempat guru dan siswa memimpin proses belajar mengajar. Ruang kelas bukan sekedar ruangan tempat anak berkumpul untuk belajar sesuatu dari guru, kelas merupakan komunitas kecil yang mencerminkan keadaan masyarakat luas di luar sekolah.

Ruang kelas juga mempertemukan sejumlah anak dari berbagai latar belakang dan budaya sesuai dengan sukunya masingmasing menurut Nawawi (2015, p. 46). 
Perbedaan tersebut bisa menjadi salah satu faktor yang menyebabkan munculnya berbagai jenis perilaku yang ditampilkan siswa ketika mengikuti proses belajar mengajar di kelas.

Menurut Kompri (2014, p. 41) "Pengelolaan kelas merupakan usaha yang disengaja untuk mencapai tujuan pendidikan. Pengelolaan kelas merupakan masalah utama yang dihadapi oleh para guru, baik pemula maupun lanjutan. Menurut Kompri (2014, p. 153), ada 7 kegiatan umum pengelolaan kelas: (1) Mengecek kehadiran (2) Mengumpulkan hasil kerja (3) Mendistribusikan bahan/alat (4) Mengumpulkan informasi (5) Mencatat data (6) Memelihara arsip (7) Memberikan pekerjaan rumah/pekerjaan rumah. Ini adalah masalah perilaku yang kompleks, guru menggunakannya untuk menciptakan dan memelihara kondisi kelas sehingga siswa dapat secara efektif mencapai tujuan instruksional dan memungkinkan mereka untuk belajar secara optimal.

Kondisi pembelajaran yang optimal akan tercapai jika guru dapat mengelola siswa dan peralatan mengajar serta mengendalikannya dalam suasana yang menyenangkan untuk mencapai tujuan pendidikan, serta hubungan yang baik antar siswa.Hubungan pribadi antara guru dan siswa merupakan prasyarat keberhasilan pengelolaan kelas. Menurut Suhardan, dkk (2012, p. 107) "Pengelolaan kelas adalah asosiasi individu, kelompok, sekolah dan faktor lingkungan yang mempengaruhinya. Sedangkan menurut Rouhani (2010, p. 147) "Pengelolaan kelas yang efektif merupakan syarat absolut untuk terselenggaranya proses belajar mengajar yang efektif.

Harapan dari penelitian ini adalah dapat menarik perhatian siswa dan mempengaruhi pengelolaan kelas terhadap kinerja siswa dalam pelajaran IPS. Dalam proses belajar mengajar, kondisi kelas yang nyaman akan membantu menyampaikan bahan ajar guru kepada siswa. Guru dituntut memiliki keterampilan dalam mengelola komponen pembelajaran untuk membantu suasana proses belajar mengajar berjalan efektif. Keberhasilan seorang guru dalam mengelola komponen pembelajaran akan tercermin dari hasil belajar siswa yang dirangkum dalam rapor atau metrik prestasi siswa. Karena salah satu dari sekian banyak faktor yang mempengaruhi keberhasilan belajar siswa adalah keterampilan mengajar guru, termasuk keterampilan mengelola kelas guru. Peristiwa yang dapat diamati terkait pengelolaan kelas di SMPN 7 Sungai Ambawang, Kabupaten Kubu Raya, adalah keadaan ruang kelas yang tidak rapi, banyak sampah, penataan bangku yang tidak merata, dan penataan ruang kelas. ruang kelas.

Berdasarkan observasi yang dilakukan oleh SMPN 7 Sungai Ambawang, peneliti menemukan bahwa pengelolaan kelas yang diberikan oleh guru belum dilakukan secara maksimal. Ketika belajar mengajar berlangsung, guru selalu melakukan pembelajaran dalam suasana yang monoton, kegiatan belajar mengajar tidak berubah. Pada saat pembelajaran berlangsung, ada kontrol dari guru, hanya saja guru lebih fokus untuk memasukkan siswa ke dalam formulir koreksi, sehingga tidak dilakukan pengelolaan fisik dan penataan siswa. guru, jangan membuka jendela untuk memungkinkan sirkulasi udara yang baik.

Jika ada siswa yang berkeliaran di dalam kelas selama proses belajar mengajar, guru tidak akan langsung menangani peringatan siswa tersebut. Ruang kelas yang bising akan mempengaruhi konsentrasi dan partisipasi siswa. Guru perlu lebih menerima situasi dan kondisi kelas untuk menjaga suasana kelas yang baik. Selain kemampuan guru dalam merespon situasi kelas, guru juga harus dapat membagi perhatian ketika kegiatan dilakukan dalam waktu yang bersamaan dan tidak terfokus pada kelompok atau siswa.

Berdasarkan uraian konteks di atas, peneliti ingin mempertimbangkan isu-isu ini dengan judul. "Pengaruh Pengelolaan Kelas Terhadap Hasil Belajar IPS Siswa Kelas VIII SMPN 7 Sungai Ambawang Kabupaten Kubu Raya."

\section{METODE PENELITIAN}

Metode yang digunakan dalam penelitian ini adalah deskriptif dengan pendekatan 
kuantitatif karena penelitian bertujuan untuk mengungkap atau menggambarkan suatu masalah berdasarkan peristiwa yang terjadi di lapangan. Nawawi mengungkapkan bahwa ada beberapa bentuk penelitian dalam metode deskriptif, yaitu: a) survei (investigasi), b) penelitian korelasional, c) penelitian pengembangan menurut Nawawi (2015, p. 68). Sedangkan bentuk penelitian studi hubungan (studi korelasi) bertujuan untuk mendeskripsikan hubungan antara dua variabel yaitu pengelolaan kelas dan hasil belajar siswa. Prosedur Penelitian

Prosedur penelitian ini merupakan langkah atau urutan yang harus digunakan untuk lebih maju dalam penelitian ini, ada tiga langkah yaitu langkah perencanaan, langkah pelaksanaan dan tahap penulisan laporan laporan atau tahap akhir. Pada tahap perencanaan, peneliti menyiapkan surat menyurat untuk pengumpulan data awal, terutama melakukan observasi sebelum melakukan penelitian, dilanjutkan dengan penentuan durasi pelaksanaan, penyiapan alat penelitian berupa angket pengelolaan kelas, validasi alat bantu pencarian.

Pada tahap implementasi, peneliti mulai mengumpulkan data, menyebarkan kuesioner kepada responden, dan menganalisis hasil kuesioner tentang pekerjaan responden. Sedangkan pada tahap akhir penulisan laporan atau analisis data ini, penulis menganalisis data yang diperoleh berupa laporan dan menarik kesimpulan.

\section{Populasi dan Sampel}

Populasi penelitian ini adalah seluruh siswa kelas VIII A dan kelas VIII B. Kelas VIIIA berjumlah 20 orang dan kelas VIIIB berjumlah 20 orang, sehingga jumlah siswa kelas VIII di SMPN 7 Sungai Ambawang Kabupaten Kubu Raya adalah 40 Orang. Jika populasinya kurang dari 100 orang, sampel penelitian dapat diambil $100 \%$, sedangkan jika populasinya lebih dari 100 orang, sampel penelitian dapat diambil seluruhnya antara 10$25 \%$ atau $20-25 \%$. Jadi karena jumlahnya hanya ada 40 rakyat. Sebaiknya semua mata pelajaran ini dipelajari, hal ini sesuai dengan pendapat Arikunto (2014, p. 134), yang mengatakan bahwa jika jumlah mata pelajaran kurang dari 100, lebih baik semuanya diambil dengan studi populasi.

\section{Teknik dan Alat Pengumpulan Data}

Dua teknik yang digunakan dalam penelitian ini adalah teknik komunikasi tidak langsung dan teknik tinjauan pustaka. Teknik komunikasi tidak langsung adalah cara pengumpulan data yang dilakukan dengan cara memelihara hubungan tidak langsung atau melalui perantara, berupa alat yang sudah ada sebelumnya atau alat khusus yang dirancang untuk tujuan tertentu. Kuesioner untuk penelitian ini akan diberikan kepada siswa SMPN 7 Sungai Ambawang, Kabupaten Kubu Raya.

Teknik telaah dokumen adalah suatu cara pengumpulan data dengan cara mengelompokkan/mengklasifikasikan

dokumen tertulis yang berkaitan dengan masalah penelitian, baik dari sumber pustaka maupun dari surat kabar, majalah dan sejenisnya. Teknik penelitian ini mengumpulkan data tentang subjek penelitian melalui arsip, catatan, dokumen, dll. Dokumen ini didasarkan pada hasil ujian tengah semester setiap hari untuk guru sosiologi oleh guru IPS

\section{Analisis Data}

Teknik analisis data dalam penelitian kuantitatif menggunakan statistik. Teknik analisis data yang digunakan untuk mengetahui bagaimana pengaruh pengelolaan kelas terhadap hasil belajar peserta didik adalah sebagai berikut. Menurut Saifudin Azwar (2014, p. 149) menjelaskan bahwa, penggolongan dijadikan tiga kategori yaitu: rendah, sedang dan tinggi dengan rumus sebagai berikut:

Table 1. Rumus Penggolongan Kriteria

\begin{tabular}{|c|l|l|}
\hline No & \multicolumn{1}{|c|}{ Rumus } & Kategori \\
\hline 1 & $\mathrm{X}<($ Mean $-1 \mathrm{SD})$ & Rendah \\
\hline 2 & $\begin{array}{l}(\text { Mean }-1 \mathrm{SD}) \leq \mathrm{X}< \\
(\text { Mean }+1 \mathrm{SD})\end{array}$ & Sedang \\
\hline 3 & $($ Mean $+1 \mathrm{SD}) \leq \mathrm{X}$ & Tinggi \\
\hline
\end{tabular}

Keterangan

Mean : Rata-rata

SD : Standar Deviasi

Sedangkan untuk rumus persentase yaitu:

$\mathrm{X} \%=\frac{j 2 \quad h s_{i} \quad j c \quad r}{s_{i} \quad i l} \times 100 \%$ 
Uji normalitas ini dilakukan dengan rumus one sample kolmogorov-smimov dengan menggunakan bantuan SPSS versi 21 .

Rumus Regresi Linier Sederhana.

$\hat{Y}=\mathrm{a}+\mathrm{bx}$

Keterangan:

$\hat{Y} \quad$ : Subyek dalam variabel dependen yang diprekdisikan.

a : Harga $\mathrm{Y}$ ketika harga $\mathrm{X}=0$ (harga konstan)

b : Angka koefisien regresi, Bila (+) arah garis naik, dan bila (-) maka arah garis turun.

$\mathrm{X}$ : Subyek variabel independent yang nilai tertentu.(Sugiyono, 2017, p. 261)

\section{HASIL PENELITIAN DAN}

\section{PEMBAHASAN}

\section{Hasil Penelitian}

Untuk mendapat pengaruh pengelolaan kelas terhadap hasil belajar peserta didik dapat melihat dengan cara merumuskan variabel (x) bebas dengan variabel (y) terikat. Untuk mengetahui bagaimana pengaruh pengelolaan kelas terhadap hasil belajar peserta didik kelas VIII di SMPN 7 sungai ambawang kabupaten kubu raya. Untuk menjawab sub masalah pertama, yaitu bagaimana pengelolaan kelas pada pembelajaran IPS kelas VIII peserta didik di SMPN 7 Sungai Ambawang Kabupaten Kubu Raya, maka digunakan analisis deskriptif.

Berdasarkan dari jawaban angket masing-masing responden yang terdiri dari 23 item pernyataan valid dari 40 responden. skor total pengelolaan kelas dihitung mengggunakan program aplikasi SPSS versi 21, kemudian data diolah mengggunakan program aplikasi SPSS versi 21. Berikut hasil analisis deskriptif data pengelolaan kelas.

Tabel 2 : Skor Pengelolaan Kelas

\begin{tabular}{|l|l|l|l|}
\hline No & \multicolumn{1}{|c|}{ Skor } & \multicolumn{1}{|c|}{ F } & Persen (\%) \\
\hline 1 & 46 & 1 & 2,5 \\
\hline 2 & 69 & 5 & 12,6 \\
\hline 3 & 70 & 1 & 2,5 \\
\hline 4 & 71 & 1 & 2,5 \\
\hline 5 & 72 & 2 & 5,1 \\
\hline 6 & 77 & 2 & 5,1 \\
\hline
\end{tabular}

\begin{tabular}{|l|l|l|l|}
\hline 7 & 79 & 3 & 7,6 \\
\hline 8 & 80 & 1 & 2,5 \\
\hline 9 & 81 & 1 & 2,5 \\
\hline 10 & 82 & 3 & 7,6 \\
\hline 11 & 84 & 3 & 7,6 \\
\hline 12 & 85 & 3 & 7,6 \\
\hline 13 & 86 & 3 & 7,6 \\
\hline 14 & 87 & 1 & 2,5 \\
\hline 15 & 88 & 3 & 7,6 \\
\hline 16 & 89 & 2 & 5,1 \\
\hline 17 & 90 & 2 & 5,1 \\
\hline 18 & 92 & 3 & 7,6 \\
\hline Jumlah & 40 & & 100,0 \\
\hline
\end{tabular}

Tabel 3: Mean dan Standar Deviasi Statistics

\begin{tabular}{|l|l|}
\hline & Pengelolaan Kelas \\
\hline $\mathrm{N} \quad$ Valid & 40 \\
Mean & 0 \\
Median & 80,60 \\
Mode & 83,00 \\
Std. Deviation & 69 \\
Variance & 9,276 \\
Range & 86,041 \\
Minimum & 46 \\
Maximum & 46 \\
Sum & 92 \\
\hline
\end{tabular}

Berdasarkan hasil analisis diatas menunjukkan bahwa pengelolaan kelas memiliki Mean 80,60 dan standar deviasi 9,276 . Berikut perolehan hasil angket tentang pengelolaan kelas yang dapat disajikan ke dalam tabel sebagai berikut:

Tabel 4: Perhitungan Kategori

\begin{tabular}{|l|l|l|}
\hline No & Rumus & Kategori \\
\hline 1 & $\begin{array}{l}\mathrm{X}<(80,60-1.9,276) \\
(71,3)=71\end{array}$ & Rendah \\
\hline 2 & $\begin{array}{l}(80,60-1.9,276) \leq \mathrm{X}< \\
(80,60+1.9,276)\end{array}$ & Sedang \\
& $\begin{array}{l}(71,3)=71 \leq \mathrm{X}< \\
(89,8)=90\end{array}$ & \\
\hline 3 & $\begin{array}{l}(80,60+1.9,276) \leq \mathrm{X} \\
(89,8)=90\end{array}$ & Tinggi \\
\hline
\end{tabular}

Tabel 5: Distribusi Pengelolaan Kelas \begin{tabular}{|l|l|l|l|}
\hline Interval & Kriteria & F & Presen\% \\
\hline
\end{tabular} 


\begin{tabular}{|l|l|l|l|}
\hline$<71$ & Rendah & 7 & $17,5 \%$ \\
\hline $71-90$ & Sedang & 28 & $70 \%$ \\
\hline$>90$ & Tinggi & 5 & $12,5 \%$ \\
\hline Jumlah & & 40 & $100,0 \%$ \\
\hline
\end{tabular}

Sumber: Pengolahan data primer yang diolah

Berdasarkan tabel 4.5 dapat dilihat bahwa pengelolaan kelas peserta didik kelas VIII SMPN 7 sungai ambawang, menunjukkan bahwa 17,5\% rendah, $70 \%$ sedang, dan $12,5 \%$ tinggi.

Gambar 1: Diagram Pengelolaan kelas

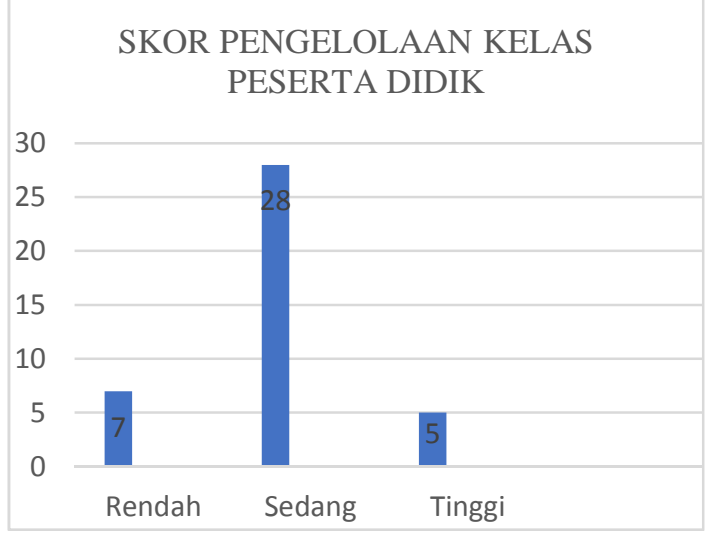

Gambar 2: Diagram Persentase Pengelolaan Kelas

\section{PERSENTASE PENGELOLAAN KELAS PESERTA DIDIK}

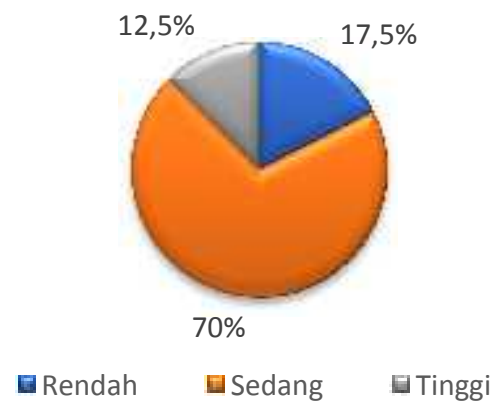

Berdasarkan diagram pada gambar 1 dan 2 dapat diketahui bahwa sebanyak 7 orang atau $17,5 \%$ peserta didik memiliki pengelolaan kelas yang berkategori rendah, 28 orang atau $70 \%$ peserta didik memiliki pengelolaan kelas berkategori sedang dan 5 orang atau $12,5 \%$ peserta didik memiliki pengelolaan kelas berkategori tinggi.

Tabel 6:Hasil Belajar pada Pembelajaran IPS

\begin{tabular}{l|l|l|} 
Hasil Belajar & Fre & Persentase (\%)
\end{tabular}

\begin{tabular}{|c|c|c|}
\hline 75 & 7 & 17,5 \\
\hline 78 & 7 & 17,5 \\
\hline 80 & 14 & 35,0 \\
\hline 82 & 4 & 10,0 \\
\hline 83 & 1 & 2,5 \\
\hline 85 & 5 & 12,5 \\
\hline 90 & 2 & 5,0 \\
\hline Jumlah & 40 & 100,0 \\
\hline
\end{tabular}

Sumber: Pengolahan data primer yang diolah Tabel 7: Mean dan Standar Deviasi Analisis data Statistics

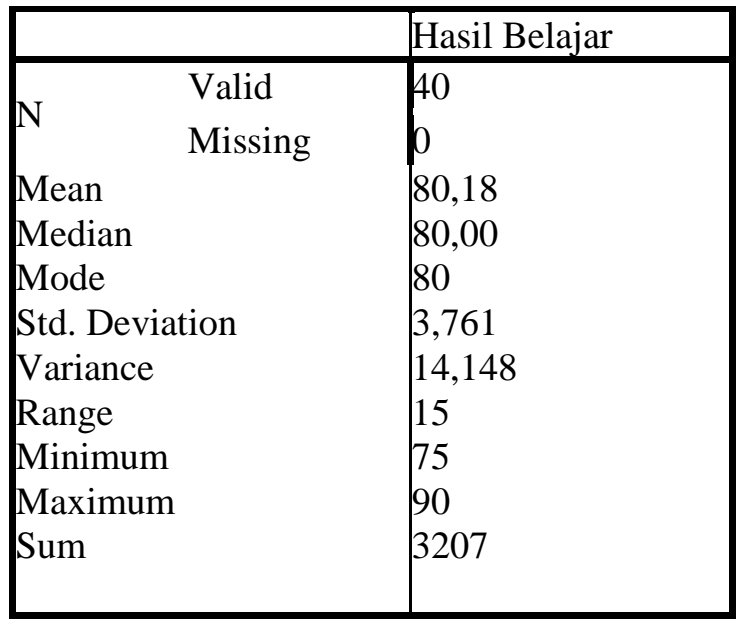

Berdasarkan hasil analisis diatas menunjukkan bahwa hasil belajar memiliki Mean 80,18 dan standar deviasi 3,761. Berikut perolehan hasil belajar yang dapat disajikan ke dalam tabel sebagai berikut:

Tabel 8: Perhitungan Kategori

\begin{tabular}{|l|l|l|}
\hline No & Rumus & Kategori \\
\hline 1 & $\begin{array}{l}\mathrm{X}<(80,18-1.3,761) \\
(76,4)=76\end{array}$ & Rendah \\
\hline 2 & $\begin{array}{l}(80,18-1.3,761) \leq \mathrm{X}< \\
(80,18+1.3,761)\end{array}$ & Sedang \\
& $\begin{array}{l}(76,4)=76 \leq \mathrm{X}< \\
(83,9)=84\end{array}$ & \\
\hline 3 & $\begin{array}{l}(80,18+1.3,761) \leq \mathrm{X} \\
(83,9)=84\end{array}$ & Tinggi \\
\hline
\end{tabular}

Tabel 9: Distribusi Hasil Belajar

\begin{tabular}{|l|l|l|l|}
\hline Interval & Kriteria & Frekuensi & Presentase \\
\hline$<76$ & Rendah & 7 & $17,5 \%$ \\
\hline $76-84$ & Sedang & 26 & $65 \%$ \\
\hline$>84$ & Tinggi & 7 & $17,5 \%$ \\
\hline Jumlah & & 40 & $100,0 \%$ \\
\hline
\end{tabular}

Sumber: Pengolahan data primer yang diolah 
Berdasarkan tabel 9 dapat dilihat bahwa hasil belajar peserta didik kelas VIII SMPN 7 sungai ambawang, menunjukkan bahwa $17,5 \%$ rendah, $65 \%$ sedang, dan $17,5 \%$ tinggi. Dengan demikian dapat disimpulkan bahwa hasil belajar pada pembelajaran IPS peserta didik kelas VIII SMPN 7 sungai ambawang dalam kriteria sedang, karena peserta didik dominan pada hasil belajar kriteria sedang. Dari hasil ini diharapkan bahwa hasil belajar peserta didik yang sedang akan memberikan kontribusi yang tinggi terhadap hasil belajar peserta didik pada pembelajaran IPS.

Gambar 3:Diagram Hasil Belajar Peserta Didik

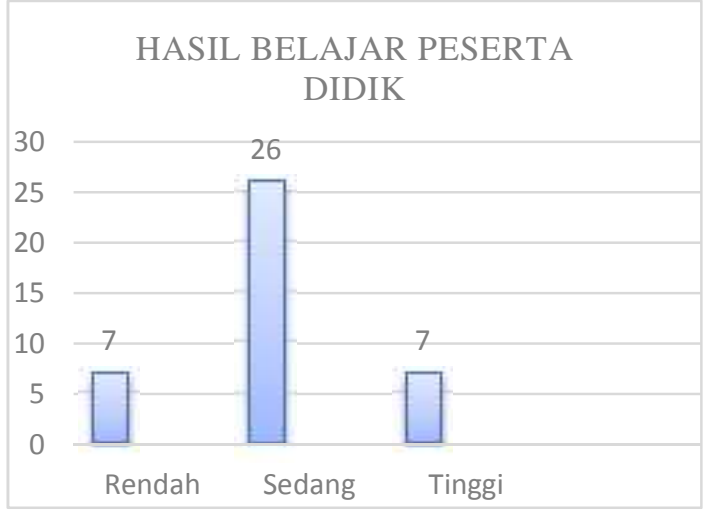

Gambar 4: Diagram Persentase Hasil
Belajar

PERSENTASE HASIL BELAJAR

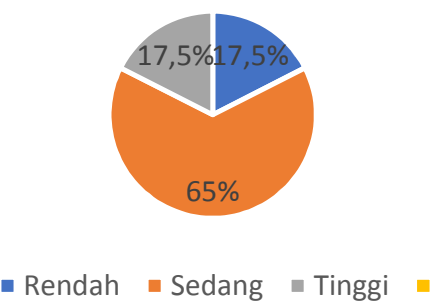

Berdasarkan diagram pada gambar 3 dan 4 dapat diketahui bahwa sebanyak 7 orang atau $17,50 \%$ peserta didik memiliki hasil belajar yang berkategori rendah 26 orang atau $65 \%$ peserta didik memiliki hasil belajar berkategori sedang dan 7 orang atau $17,50 \%$ peserta didik memiliki hasil belajar berkategori tinggi. Jadi, hasil belajar peserta didik dominan pada kriteria sedang ini akan memberikan kontribusi yang tinggi terhadap hasil belajar peserta didik pada pelajaran IPS.
Setelah diperoleh data diatas hasil belajar peserta didik dapat dilihat dari aspek nilai rata-rata ulangan harian semester genap yang dilaksanakan diseolah dengan Kriteria Ketuntasan Minimum (KKM) yaitu 75,00. Hasil belajar peserta didik ditunjukan pada table sebagai berikut.

\section{Tabel 10: Diskriptif Hasil Belajar}

\begin{tabular}{|l|l|l|l|}
\hline No & Kriteria & F & Persen(\%) \\
\hline 1 & Tuntas & 40 & $100 \%$ \\
\hline 2 & Tidak Tuntas & 0 & $0 \%$ \\
\hline & Jumlah & 40 & $100 \%$ \\
\hline
\end{tabular}

Sumber: pengelolaan data primer

Pengaruh Pengelolaan Kelas Terhadap Hasil Belajar Pada Mata Pelajaran IPS

Pada pembahasan pada bab sebelumnya telah dijelaskan bahwa untuk menganalisis data dalam penelitian ini menggunakan teknik perhitungan regresi sederhana dengan bantuan Program Statistic and Service Solution (SPSS) versi 21. Untuk perhitungan data sebagai berikut:

Tabel 11: Nilai Variabel $X$ dan Variabel $Y$

\begin{tabular}{|c|c|c|}
\hline No & Variabel X & Variabel Y \\
\hline 1 & 92 & 90 \\
\hline 2 & 88 & 90 \\
\hline 3 & 79 & 85 \\
\hline 4 & 71 & 75 \\
\hline 5 & 69 & 75 \\
\hline 6 & 92 & 85 \\
\hline 7 & 69 & 75 \\
\hline 8 & 82 & 80 \\
\hline 9 & 77 & 80 \\
\hline 10 & 84 & 78 \\
\hline 11 & 79 & 80 \\
\hline 12 & 92 & 85 \\
\hline 13 & 79 & 78 \\
\hline 14 & 72 & 75 \\
\hline 15 & 69 & 75 \\
\hline 16 & 84 & 80 \\
\hline 17 & 90 & 85 \\
\hline 18 & 46 & 75 \\
\hline 19 & 88 & 80 \\
\hline 20 & 69 & 78 \\
\hline 21 & 81 & 80 \\
\hline 22 & 90 & 75 \\
\hline 23 & 70 & 80 \\
\hline 24 & 87 & 82 \\
\hline 25 & 89 & 80 \\
\hline & & \\
\hline
\end{tabular}




\begin{tabular}{|l|l|l|}
\hline 26 & 77 & 78 \\
\hline 27 & 72 & 80 \\
\hline 28 & 80 & 78 \\
\hline 29 & 89 & 83 \\
\hline 30 & 82 & 80 \\
\hline 31 & 85 & 80 \\
\hline 32 & 88 & 80 \\
\hline 33 & 86 & 82 \\
\hline 34 & 85 & 80 \\
\hline 35 & 84 & 78 \\
\hline 36 & 82 & 80 \\
\hline 37 & 85 & 82 \\
\hline 38 & 86 & 85 \\
\hline 39 & 86 & 82 \\
\hline 40 & 69 & 78 \\
\hline
\end{tabular}

Sumber: Pengolahan Data Primer yang diolah

Setelah mendapat data dari angket pengelolaan kelas dan hasil belajar selanjutnya peneliti melakukan analisis data tersebut.

Uji Normalitas

Salah satu syarat yang harus dipenuhi dalam analisis regresi linier sederhana adalah data dan model regresi berdistribusi normal. Kenormalan data dapat dilihat dari uji normalitas kolmogorov-smirnov dari masingmasing variabel. Analisis data ini menggunakan bantuan program SPSS versi 21. Dasar pengambilan keputusan berdasarkan pada probabilitas $>0,05$ maka data penelitian berdistribusi normal. Hasil uji normalitas dapat dilihat dari output SPSS versi 21 seperti pada tabel berikut:

Tabel 12: Uji Nomalitas One-Sample

Kolmogorov-Sminov Test

One-Sample Kolmogorov-Smirnov Test

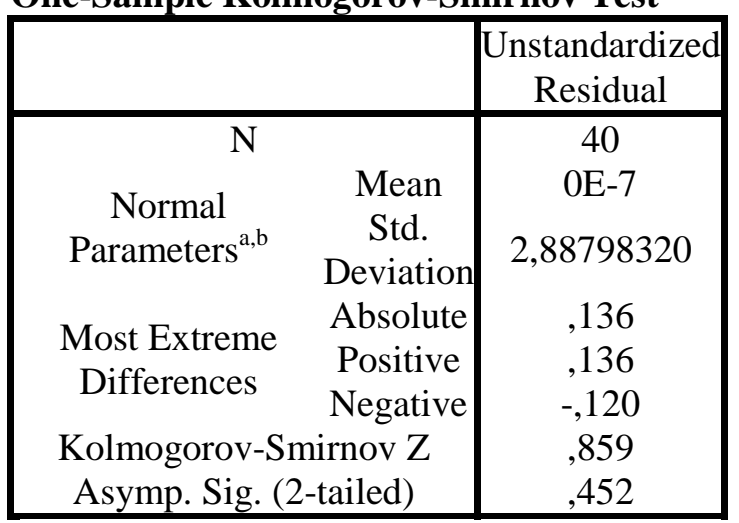

a. Test distribution is Normal.

b. Calculated from data.

Berdasarkan tabel 4.13 Menunjukkan bahwa pada Asymp. Sig. (2-tailed) diperoleh nilai signifikasi 0,452 > 0,05 yang artinya bahwa nilai residual berdistribusi normal, sehingga hasil analisis ini dapat dilanjutkan keanalisis regresi linear sederhana. Analisis Regresi Linear Sederhana

Untuk menjawab sub masalah ketiga yaitu seberapa besar pengaruh pengelolaan kelas terhadap hasil belajar peserta didik, maka digunakan teknik analisis perhitungan regresi linier sederhana dengan menggunakan bantuan program SPSS versi 21. Analisis regresi linier sederhana digunakan untuk mengetahui pengaruh antara satu buah variabel bebas terhadap variabel terikat.

Tabel 13: Hasil Perhitungan Regresi Linier Sederhana

Coefficientsa

\begin{tabular}{|c|c|c|c|c|c|}
\hline Model & $\begin{array}{c}\text { Unstandardiz } \\
\text { ed } \\
\text { Coefficients }\end{array}$ & $\begin{array}{c}\text { Standardiz } \\
\text { ed } \\
\text { Coefficien } \\
\text { ts }\end{array}$ & T & Sig \\
\cline { 2 - 4 } & B & $\begin{array}{c}\text { Std.Err } \\
\text { or }\end{array}$ & Beta & & \\
\hline \begin{tabular}{l|c|c|c|} 
(Consta \\
nt)
\end{tabular} & 59,23 & 4,097 & & $\begin{array}{c}14,45 \\
8\end{array}$ & 0 \\
$\begin{array}{l}1 \text { Pengelo } \\
\text { laan } \\
\text { Kelas }\end{array}$ &, 260 &, 051 &, 641 & 5,144 & 0 \\
\hline
\end{tabular}

a. Dependent Variable: Hasil Belajar

Dari tabel 13 Data dilihat, nilai-nilai tersebur dimasukkan kedalam persamaan regresi sebagai berikut:

$\mathrm{Y}=\mathrm{a}+\mathrm{bX}$

$\mathrm{Y}=59,235+0,260 \mathrm{X}$

Hasil dari persamaan regresi linier sederhana tersebut dapat diartikan sebagai berikut:

Nilai konstanta (a) adalah 59,235 artinya jika pengelolaan kelas peserta didik bernilai 0 (nol), maka hasil belajar bernilai positif yaitu 59,235 .

Nilai koefisien regresi pengelolaan kelas peserta didik (b) bernilai positif yaitu 0,260 maka dapat diartikan bahwa setiap peningkatan pengelolaan kelas sebesar 1, maka hasil belajar juga akan meningkat sebesar 0,260. Variabel dikatakan signifikan jika $<0,05$ sedangkan hasil penelitian 
menunjukkan $0,000<0,050$ yang artinya memiliki nilai yang signifikan.

\section{Uji Koefisien Determinasi $\left(\boldsymbol{K}^{2}\right)$}

Koefisien determinasi $K^{2}$ digunakan untuk mengukur seberapa besar pengaruh antara pengelolaan kelas terhadap hasil belajar. Angka dari R square diubah kedalam bentuk persen yang artinya untuk mengetahui seberapa besar persentase pengaruh variabel independen terhadap variabel dependen.

Tabel 14: Hasil Koefisien Determinasi $K^{2}$ Model Summaryb

\begin{tabular}{|l|c|c|c|c|}
\hline Model & $R$ & $\begin{array}{c}R \\
\text { Square }\end{array}$ & $\begin{array}{c}\text { Adjusted R } \\
\text { Square }\end{array}$ & $\begin{array}{l}\text { Std. Error of } \\
\text { the Estimate }\end{array}$ \\
\hline 1 & $, 641 \mathrm{a}, 410$ &, 395 & 2,92574 \\
\hline
\end{tabular}

a. Predictors: (Constant), Pengelolaan Kelas

b. Dependent Variable: Hasil Belajar

Dari tabel 14 diatas didapatkan nilai $R$ square sebesar 0,410 yang artinya pengaruh pengelolaan kelas terhadap hasil belajar sebesar $41 \%$, sedangkan sisanya $59 \%$ dipengaruhi oleh faktor lain yang tidak dikaji dalam penelitian ini.

\section{Pembahasan}

Pengelolaan kelas sebagai belajar adalah suatu hal penting yang harus dilakukan oleh peserta didik agar siap dalam menghadapi berbagai situasi lingkungan didalam kelas. Pengelolaan kelas untuk belajar menjadi faktor yang dianggap berpengaruh terhadap hasil belajar peserta didik. Hasil penelitian menunjukkan bahwa pengelolaan kelas pada pembelajaran IPS peserta didik kelas VIII SMPN 7 sungai ambawang berkategori rendah 7 orang dengan persen $17,50 \%$ berkategori sedang 28 orang dengan persentase $70 \%$ berkategori tinggi 5 orang dengan persentase $12,50 \%$ dari jumlah persentase keseluruhan.

Hasil penelitian ini juga menunjukkan bahwa hasil belajar yang dimiliki peserta didik kelas VIII SMPN 7 sungai ambawang yang diperoleh dari nilai rata-rata ulangan harian pada semester genap dan melihat Kriteria Ketuntasan Minimal (KKM) yaitu 75,00 . Hasil belajar pada pembelajaran IPS menunjukkan bahwa terdapat 40 orang peserta didik dengan persentase $100 \%$ berkategori tuntas dan 0 peserta didik dengan persentase $0 \%$ berkategori tidak tuntas, dengan nilai rata- rata 80,18. Dengan demikian dapat disimpulkan bahwa hasil belajar peserta didik pada mata pelajaran IPS tergolong sangat kuat karena banyak peserta didik yang tuntas.

Berdasarkan data yang telah diolah menggunakan bantuan SPSS versi 21 uji normalitas diperoleh signifikasi sebesar 0,452 . Nilai signifikasi. 0,452 > 0,05 yang artinya bahwa nilai residual berdistribusi normal, sehingga hasil analisis ini dapat lanjut ke analisis regresi linier sederhana.

Berdasarkan perhitungan uji regresi linier sederhana diperoleh persamaan 59,235 + $0,260 \mathrm{X}$ yang berarti nilai konstanta (a) adalah 59,235 artinya jika pengelolaan kelas bernilai nol, maka hasil belajar bernilai positif yaitu 59,235. Nilai koefisien regresi variabel pengelolaan kelas bernilai positif yaitu 0,260 , ini berarti dapat menunjukkan bahwa setiap peningkatan pengelolaan kelas sebesar 1 maka hasil belajar akan meningkat 0,260 .

Berdasarkan hasil uji $R^{2}$ diperoleh nilai sebesar $41 \%$. Besarnya pengaruh pengelolaan kelas terhadap hasil belajar yaitu sebesar 0,410 yang artinya persentase pengelolaan kelas berpengaruh terhadap hasil belajar sebesar $41 \%$ sedangkan sisanya $59 \%$ dipengaruhi oleh variabel lain yang tidak dikaji dalam penelitian ini. Walau pun kadar pengaruhnya lemah, tetapi pengelolaan kelas memberikan pengaruh yang positif terhadap hasil belajar pada pembelajaran IPS. Jadi terdapat pengaruh positif yang signifikan antara pengelolaan kelas terhadap hasil belajar peserta didik kelas VIII pada pembelajaran IPS SMPN 7 Sungai Ambawang Kabupaten Kubu Raya.

\section{SIMPULAN DAN SARAN \\ Simpulan}

Hasil pengolahan data menunjukan Pengelolaan kelas VIII SMPN 7 Sungai Ambawang Kabupaten Kubu Raya berkatagori sedang yaitu sebanyak 28 orang (70\%), berkatagori rendah sebanyak 7 orang $(17,50 \%)$, berkatagori tinggi 5 orang $(12,50 \%)$.

Hasil belajar pada pembelajaran IPS kelas VIII SMPN 7 Sungai Ambawang Kabupaten Kubu Raya diperoleh dari hasil 
dokumentasi dari nilai ulangan harian pada semester genap tahun ajaran 2019/2020 dari guru mata pelajaran IPS yang bersangkutan. Hasil pengolahan data yang dilakukan secara statistik deskriptik dan melihat dari (KKM) 75,00 menunjukkan bahwa hasil belajar peserta didik pada pembelajaran IPS berkategori tinggi 7 orang $(17,5 \%)$ dengan nilai $>84$, sedang 26 orang sebesar $(65 \%)$ dengan nilai antara $76-84$, rendah 7 orang $(17,5 \%)$ dengan nilai < 76 . Ini terdapat 40 orang peserta didik dengan persentase $100 \%$ berkategori tuntas dan 0 peserta didik dengan persentase $0 \%$ berkategori tidak tuntas, dengan nilai rata-rata 80,18.

Berdasarkan hasil penelitian peneliti memiliki pengaruh yang signifikan dengan nilai koefesien regresi variabel bernilai positif sebesar 0,260 ini menunjukan setiap peningkatan pengelolaan kelas sebesar 1 maka hasil belajar akan meningkat 0,260 . Hasil uji t diperoleh $\mathrm{t}$ hitung > nilai $\mathrm{t}$ tabel $(2,068>$ 2,04523) dengan demikian Ho ditilak dan $\mathrm{Ha}$ diterima. Besar pengaruh pengelolaan kelas dengan hasil belajar peserta didik sebesar $\mathrm{R}$ 0,410 artinya persentase pengaruh pengelolaan kelas terhadap hasil belajar adalah $41 \%$ dan sisanya 59\% dipengaruhi oleh variabel lainya.

Saran

Bagi guru selalu memberikan kenyamanan, tanggung jawab, konsisten pada saat memulai pelajaran selalu memperhatikan peserta didiknya karena peserta didik pada jenjang ini mereka lebih bosan terhadap pembelajaran yang monoton, jika terus menerus maka peserta didik akan jenuh sehingga akan menurunkan minat belajar peserta didik tersebut.

Bagi peserta didik harus tetap menjaga lingkungan kelas, lingkungan sekolah, sealau berpikir positif disaat menerima pelajaran tanpa melihat kelebihan atau kekurangan lingkungan kelas tersebut agar bias tercapainya hasil belajarnya dengan baik.

Bagi peneliti selanjutnya penelitian yang telah diteliti oleh penulis berpengaruh sebesar $41 \%$ dan sisanya $59 \%$ dipengaruhi oleh variabel lainya, saran dari peneliti selanjutnya supaya melakukan penelitian ini dari variabel lainnya agar dapat mempengaruhi hasil belajar yang lebih baik lagi secara generalisasi.

\section{DAFTAR RUJUKAN}

Arikunto, S. (2014). Prosedur Penelitian Suatu Pendekatan Praktek. Jakarta: Rineka Cipta.

Barnadib, S. I. (2010). Pengantar ilmu pendidik sistematis. Bandung: FIP IKIP.

Djamarah, S. B. dan Zain, A. (2010). Strategi Belajar Mengajar. Jakarta: PT Renika Cipta.

FKIP UNTAN. (2019). Pedoman Penulisan Karya Ilmiah, Pontianak: Edukasi Press FKIP UNTAN

Hasbullah. (2014). Dasar-dasar ilmu pendidikan. Jakarta: Rajawali pers.

Kompri. (2014). Manajemen Sekolah Teori\&Praktek. Bandung: Alfabeta.

Latuconsina, N. K. (2013). Pengelolaan kelas dalam pembelajaran. Makassar: Alauddin University pers.

Nawawi, H. (2015). Metode Penelitian Bidang Sosial. Yogyakarta: Gajah

Mada University Press.

Noviyanti, D. (2016). Pengaruh pengelolaan kelas dalam pembelajaran IPS tehadap hasil belajar siswa SD Negeri 20 palu kecamatan palu barat. Elementary school of education e-jurnal 8,PGSD,FIKIP, Universitas Taduluko.

Rohani, A. (2012). Pengelolaan dan pengajaran. Jakarta: Renika Cipta.

Rusdiana. (2015). Pengelolaan atau Manajemen Pendidikan. Bandung: cv pustaka setia. 
Suhardan, D. dkk. (2012). Manajemen Pendidikan. UPI. Bandung: Alfabeta.

Sugiyono. (2018). Metode Penelitian Pendidikan Pendekatan Kuantitatif, Kualitatif Dan $R \& D$. Bandung: Alfabert.
Sugiyono. (2019). Metode Penelitian Kuantitatif. Bandung: Alfabert. Undang-Undang Republik Indonesia Nomor 20 Tahun 2003 tentang sistem pendidikan nasional, Jakarta: Sinar Grafika. 